Historic, Archive Document

Do not assume content reflects current scientific knowledge, policies, or practices. 



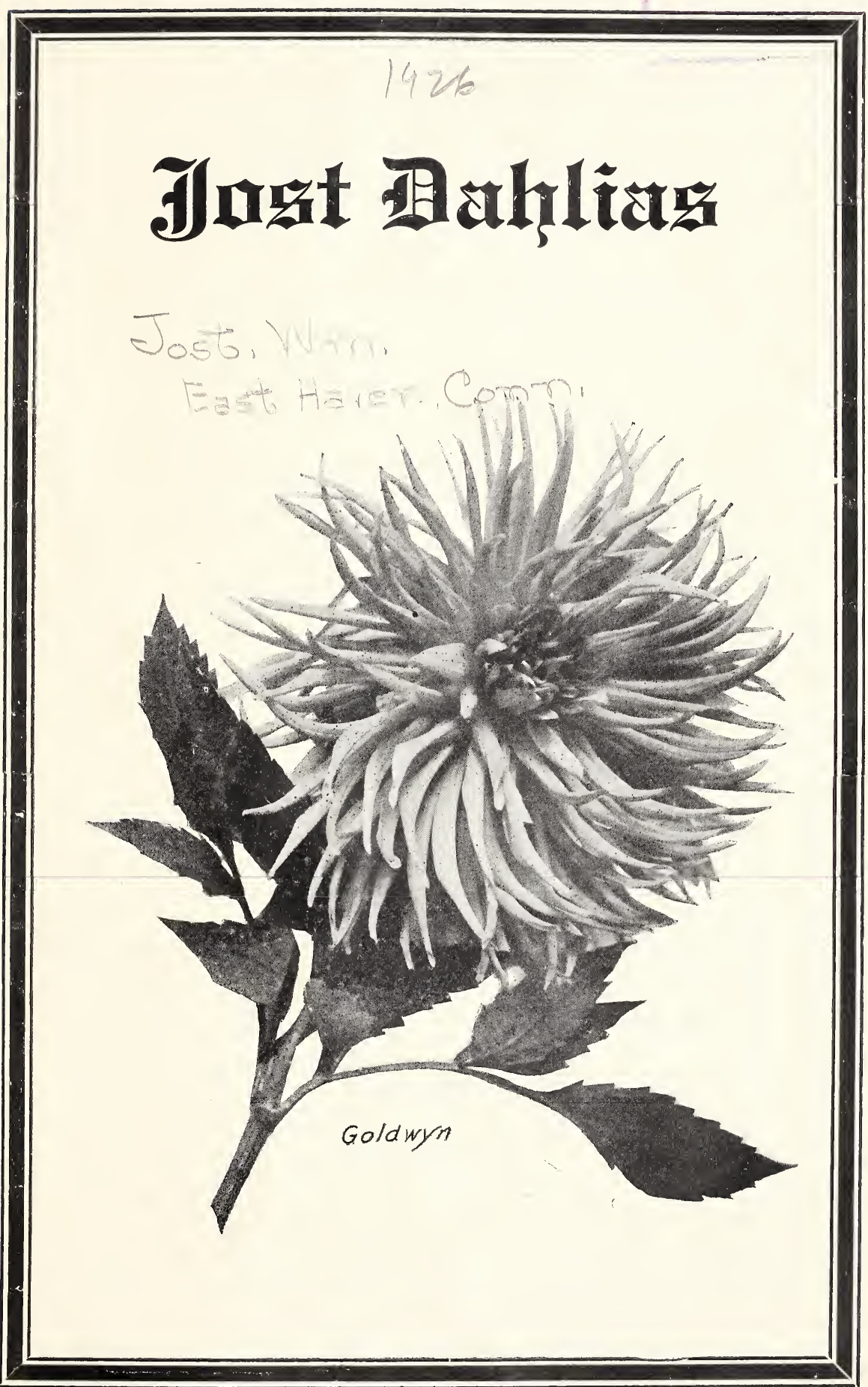


i

$$
1
$$

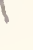




\section{WM. F. JOST \\ DAHLIA GROWER \\ AND \\ ORIGINATOR \\ 1926}

GOLD MEDAL New York, 1921 for New Cactus

BRONZE MEDAL New Haven, 1922

\author{
W. W. Darnell \\ SILVER CUP \\ for "Maulmain" \\ Best Keeping Cut \\ Flower
}

312 Dodge Avenue EAST HAVEN, CONN. 


\section{Greetings!}

Am taking great pleasure in presenting to my many customers and friends, this catalog of dahlias which comprises varieties of my own introduction and the cream of other raisers.

Am also taking this opportunity of thanking my good friends for their past favors.

Have erery confidence in highly recommending my own introductions, stock of some varieties is rather limited, when my stock of tubers are sold out, will supply green plants, if desired.

Terms: Prices are for divided field grown roots or green plants, either will give equally good results; in fact, green plants are preferred by experienced growers.

Cash must accompany all orders from unknown correspondents.

Remittance should be made by Money Order, Bank Draft or Express Money Order.

Shipping - In filling out your order always give Shipping Directions, and write Name and Address distinctly.

Non-Warranty - I guarantee all roots and plants to be healthy and true to name, but will not be in any way responsible for the crop.

Stock of some varieties is low, so early orders are advisable.

No substitution unless directed.

This list cancels all previous prices. 


\title{
CATALOG OF DAHLIAS
}

\author{
KEY \\ "Cac" Cactus \\ "S" Show \\ "P" Peony \\ "Dec" Decorative \\ "H. C." Hybrid Cactus \\ "*" Jost
}

AMUN RA. Resembles the setting sun. Outer petals are of gorgeous shades of copper and orange, shading to gold and amber, deepening to a rich dark, reddish bronze at the center.

Plants only, $\$ 1.00$

ABUNDANCE. Dec. * White, with a suffusion of delicate pale pink, distinctly striped yellow, the reverse petals of a lovely pink, make this an unusually attractive variety, and an ideal cut flower.

Plants 50c; Tubers $\$ 1.00$

AMBASSADOR C. Cac. The floral sensation of Los Angeles; the color is soft yellow buff, shaded salmon-pink; flowers of pleasing form, and enormous size, the splendid flowers are held erect well above the foliage on the strongest stems I have ever seen on a Cactus Dahlia; nothing better has ever been produced than this American type of Cactus Dahlia.

Plants $\$ 1.00$; Tubers $\$ 2.00$

AGNES HAVILAND. Color rose-pink, slightly suffused yellow; the flowers are borne on long stems, well out from the foliage; a tall robust grower.

Plants only, $\$ 1.00$

BERTHA JOST. Dec. * Base deep sulphur. Outer petals blendid with peach pink, the entire centre tinted with burnt orange. A very handsome free-flowering large dahlia, carried on long stiff stems.

Plants $\$ 1.00$; Tubers $\$ 2.00$

BEN WILSON. Dec. Of perfect form, bright red faintly striped with gold, very distinct and attractive, free flowering.

Plants $\$ 1.00$; Tubers $\$ 1.50$

BOSTON WHITE. Dec. One of the best whites, a fine flower on strong stems.

Plants only, $\$ 1.00$

BOB NEWCOMB. Dec. The color of this extra large flower has a charm you cannot resist. It reaches the plum and burgundy tones. A true decorative type full to the centre and of great depth. It has an unusually long stiff stem, and a profuse bloomer both early and late.

Plants only, $\$ 1.00$

BETTY RIKER. Dec. * A very large flat decorative, a two color dahlia a shade of orange and red striped, very often having as many red blossoms on one plant as there are striped. This is a novelty and a fine garden dahlia, free and a big attraction in any garden, not a cut flower for market, it is much too large for that. 
BIUE BIRD. P. A beautiful peony with broad petals in amaranth pink, shading to lilae. Tery large; blooms early and late.

Plants only, $75 \mathrm{c}$

C. H. DRESEELHUIS. For many years the variety Delice has been a farorite cut flower, and while beautiful it was not free-flowering. In this new variety we have a similar color, a soft rose-pink with white suffusion towards the tips, and what is most important, one of the most prolific bloomers; of medium size just right for cutting and are splendidly supported on rery long stiff stems. We predict great popularity for this rariety as it is undoubtedly the best pink for cutting ret produced.

Plants $750 ;$ Tubers $\$ 1.00$

CHAMPACNE. Dec. Chamois with pink suffusion, very large handsome flower on gockl stems.

Plants $\$ 1.50 ;$ Tubers $\$ 3.00$

DOROTHY DURNBATGH. Cac. \& most aitractive shade of deep ricl pink, flowers are immense in size; of fine form and habit, with strong stems that hold up well; one of the best cactus dahlias in cultiration, fine for eutting. Strong field grown tubers. Plants only, 75 e

DORIS FARRELL. Dee. * A lively shade of lilac pink with lighter suffusion. Fine for cutting:

Plants 75c; Tubers $\$ 1.00$

DR. MARSHALL A. HONE. Dec. (Broomall) Very light lavender pink. large, attractive in form and color, strong grower, medium stem.

Plants only, \$1.00

EDITH CAVELI. Dec. Flowers carried on long stiff stems, perfeetly formed of pleasing flame color shading to a reddish buff on the outer petals, splendid for garden decoration.

Plant only, 50e

ETHEL MOWER. Dec. * Fine large flower, exceptionally geod grower and very free, an exquisite shade of shell pink, carried on long stiff stems. There is a big demand for this variety.

Plants $\$ 1.00$; Tubers $\$ 1.50$

EIDOPADO. Dec. Size, stem and color of this variety are of the best. Picture a comparatively low growing bush with immense goldenvellow blooms which stand up and look yo uin the face, and you have Eldorado. A strong feature of this beauty is the depth of the flower which corresponds with the size, a splendid dahlia in every way.

Plants $\$ 2.50$; Tubers $\$ 5.00$

E. T. BEDFORD. Fine exhibition flowers of purple with a lighter shading giving it the appearance of a silvered purple tone.

Plants $\$ 1.00$; Tubers $\$ 2.00$

EMMA MAPIE. A favorite Hvbrid Cactus because of its pleasant shade of clear pink with a creamy white center and its combination of exhibition and commercial qualities not found in many Dahlias. It is a robust grower, producing deep full-centered blooms averaging eight inches in diameter on three to four foot stems in ordinary field culture. 
EASTERN STAR. This dahlia scored 87 exhibition and 88 commercial at the Dahlia Society trial grounds, 1924. Color is a soft saffron yellow with old gold shadings. Flowers of great substance and remarkable keeping qualities. Full centers and are held erect on strong stems. Excellent bush growth and free flowering.

Plants $\$ 5.00$; Tubers $\$ 10.00$

F. W. FELLOWS. Cac. One of the very best cactus varieties ever raised, with flowers of unusual size for the long narrow petaled type of which this is one of the best representatives. In color it is an intense coral red with deeper suffusion at the center; no collcetion of dahlias is complete without it.

Plants 75c; Tubers $\$ 1.00$

FIRELIGHT. Dec. (Marean) Yellow tipped red, medium to large, form and stem good.

Plants $\$ 1.50 ;$ Tubers $\$ 3.00$

FORT WASHINGTON. Dec. This fine dahlia like many others was originated by Mr. Herman Rindfleisch of Mamaroneck, N. Y., grows to a great height, is a dark mahogany red, and the largest dahlia I have ever grown. It is new and stock is limited for that reason, when tubers are sold out one need not be afraid to take plants of this strong growing variety. I grew them from plants to the height of 8 and 10 feet with stalks as thick as one's wrist.

Plants $\$ 10.00$; Tubers $\$ 20.00$

GOLDWYN. Cac. * (See cover) This variety was awarded the Gold Medal by The American Dahlia Society at their N. Y. Show 1921. All visitors to my garden have been loud in their praise regarding this variety, large well formed flowers of the highest type of English cactus, but with a stronger stem than any other cactus of its type. In color an exquisite blending of cream and pink being unusual in any other true cactus variety I can recall.

Plants only $\$ 1.50$

GLADYS BATES. American cactus, a splendid flower and profuse bloomer, stem erect, the color is a shade of tan and rose. Plants only, 75c

GEISHA. P. The most popular of all dahlias. The dahlia that made the peony famous. A stunning mixture of scarlet and gold.

Plants only, 75c

GEORGE WALTERS. H. C. An enormous hybrid cactus. The color is pinkish salmon shading to yellow at the base. Plants are strong growers and have every good habit. I can highly recommend this variety.

Plants only, $75 \mathrm{c}$

GLORY OF NEW HAVEN. Large flowers with beautiful broad twisting petals, which make this variety unusually tatractive; the flower is a clear lavender pink, distinctly veined deeper lavender, produced on long, stiff stems; an ideal cut flower.

Plants only, 75c

GEORGE W. A very large flower very much like the old Sulphurea but a little darker in shade and much deeper heavier flower. 
HAZEL MELTON. Dec. * A rariety rery much admired by all visitors this year, some deseribing it henna, certainly a most unusual color and difficult to describe, a suffusion of deepest bronze and brick red with a silvery sheen, flowers carried on stiff wiry stems and freely produced, this rariety is sure to become popular.

Plants $\$ 1.00 ;$ Tubers $\$ 1.50$

HORTLIANUS FIET. Dec. Large flomers of an exquisite shade of salmon pink, shading to yellow in the center. Plants $75 c$; Tubers $\$ 1.00$

HELEX DIRIBALGH. D). A pleasing shaped flower with fine upright habits. The blooms are very beautiful. The color is a soft white shading to a glowing pink deep in the flower. Plants only, 50c

JEAX CHAZOT or GAY PAREE. This has been well described as "an autumn tinted dahlia". "The color is a golden bronze heightened by a suffusion of nasturium red.

Plants only, $\$ 1.00$

J. J. McQUIGCAN. Dec. * A good grower, producing unusually large flowers of a deep sulphur vellow, carried on long stiff stems, very free flowering:

Plants only, $\$ 1.00$

IOSEPHINE MENDILLO. H. C. * Well formed flower of medium size carried on long stiff stems, color an intense velyety red, considered by many growers as being the best red hybrid cactus to date. Without cloubt the icleal red dahlia for cut flowers. What the Garden Magazine says of this dahlia: "A brilliant red hybrid eactus that seems to be an improvement on Kalif. This flower has fine substance, is a good keeper and for those who rant a new commer('ial red, it is ideal."

Plants $\$ 1.00$; Tubers $\$ 2.00$

JERAEY BEAUTY. The most distinctive new dahlia shown in the East and the finest pink dahlia in existence, a real rose pink of excellent conformation and borne on a wonderful stem.

Plants $\$ 1.00 ;$ Tubers $\$ 2.00$

JERSEY'S PRIDE. Dec. Immense flowers on good stems. A rery pleasing combination of buff, yellow and pink.

Plants only, $\$ 1.00$

KATHERINE LYONS. Dec. * Large wellformed flowers carried on long stiff stems, a pleasing shade of cream suffused with an exquisite shade of salmon rose, very free flowering. What the Garden I Iagazine sars of this dahlia: "This is not a 1924 intrcduction but for the first time was shomn in good form. The color is clear salmon rose flushed with silver and orange shadings. The flowers are of fine form and substance. Altogether it has the aualities to make it a popular variety.

Plants $\$ 1.50$; Tubers $\$ 2.50$

KITTIE DUNLAP. A delightful new shade of American Beauty Rose, having excellent keeping qualities, long firm stems, immense size, and perfect formation. We consider this beautiful Dahlia one of the best. 
LUCIFER. Dec. * An intense velvety red shading to a lighter red on the outside petals, the flowers are of large size, on good stiff stems, and produced freely.

Plants $\$ 1.00 ;$ Tubers $\$ 1.50$

MAULMAIN. H. C. * An ideal variety either for garden decoration or exhibition, medium sized flowers carried on exceptionally long stems, center petals clear yellow passing to an exquisite shade of salmon buff, an unusual and attractive combination of color, and a fine keeper when cut. This dahlia won the W. W. Darnell Silver Cup for best keeping cut flower.

Plants only, $\$ 1.00$

MARY MURPHY. Dec. 'This very fine Dahlia was originated by Mr. A. G. Goodacre, and is a large yellow and apricot on a fine stem, a true decorative, a seedling of Amun Ra.

Plants only, $\$ 5.00$

MRS. WARNAAR. H. C. Creamy white, with suffusion of flesh pink, a most exquisite flower, very free flowering and fine for cutting.

Plants 75c; Tubers $\$ 1.00$

MRS. A. R. GALLATIN. P. Soft shade of yellow, suffused light red, good stems and very free flowering, a fine flower. Plants only, $\$ 1.00$

MRS. E. C. BOSTON. Dee. The very best white decorative, for it is good in any climate and does not burn in the sunshine. Large regularly formed flower of great depth which holds its center to the end of the season. Best stem and good for any purpose.

Plants $\$ 1.00 ;$ Tubers $\$ 1.50$

MRS. JOHN L. EMERSON. Dec. Flowers of large size, well formed, of a pleasing combination of red and gold, the petals distinctly edged and striped with gold, a most attractive variety and ideal for garden decoration.

Plants $75 \mathrm{c}$

MRS. WM. J. ROWE. Dec. Very large flowers, freely produced, in color a delicate amber shading to clear yellow, a most useful variety for garden or exhibition purposes.

Plants $75 \mathrm{c} ;$ Tubers $\$ 1.00$

MRS. NIXON. Cac. Fine large flower, deep coral pink shading to a lighter pink toward the center, carried on long wiry stems, an ideal variety.

Plants only, 75c

MRS. I. de VER WARNER. Dec. One of Judge Marean's best creations. Very large, beautiful flowers of fine form. Color a rosy mauve. Stems very long and rigid. A splendid exhibition variety.

Plants only, 75e

MISS BAY STATE. Dec. An extremely large creamy white, profuse bloomer on good stems.

Plants $\$ 1.00$; Tubers $\$ 1.50$

MEPHISTOPHELES. Dec. Rich ruby?red with golden-yellow tips. The variety is magnificent in every way; of largest size, attractive formation and unique coloring.

Plants 75c; Tubers $\$ 1.00$

MILDRED BURTON. P. An extremely large flower composed of many curled and twisted petals. The color is deep golden yellow with apricot suffusions.

Plants only, $75 \mathrm{c}$ 
MRS. E. P. JUDD. Dec. Carmine and rose suffused with cream, a rery large handsome flower carried on a good strong stem. If you want the largest dahlia, get this one.

Plants $\$ 1.50$; Tubers $\$ 2.00$

MRS. JOHN L. GARDENER. H. C. Red with pure white tips; never has sported; winner of the Trenton Dahlia Society's silver medal for 1922, gold medal for best 3 year old, 1923 .

Plants only, $\$ 1.50$

MR. CRONIEY. Dec. A beautiful flower, outer petals a matermelon pink, center cream.

Plants 75c; Tubers $\$ 1.00$

MABEL THATCHER. Dec. Large flowers of a pale yellow shade, are borne on stiff, strong stems, they are of the finest type and considered the highest perfection attained in this shade. Plants only, $\$ 1.50$

MARION MCCREEDI. Dec. * Large flowers of perfect form of an intense velvety crimson shading to a carmine red towards the outer petals, exceptionally good growers, and very free flowering.

Plants $\$ 2.00$; Tubers $\$ 4.00$

MAURICE FULD. Dec. Beautiful pink, way and twisting petals. Fine for cutting and exhibition. This dahlia has the finest stems and very free flowering.

Plants only, $75 c$

MRS. II. D'ARCY RYAN (Bsesie Boston). A lovely autumn-tinted decorative. What color is it exactly? This is rather hard to answer, as the bushes bear blossoms of gleaming old gold and also coppercolored ones. Flowers are large and regularly formed and hold their heads up proudly on perfectly stiff stalks. Plants only, $\$ 1.50$

MARIPOSA. H. C. A recent introduction which has quickly become very popular. The color is a clear shade of lavender pink intensified by the full and darker center. The flowers are large and of a rather loose type made up of long ribbon-like petals which twist and curl in a most attractive manner. The stems are exceptionally long and perfect in every way.

Plants only, $\$ 1.50$

NAZARENO. Dec. * A beautiful new dahlia that is bound to become popular, for it has so many good qualities, a free bloomer, large flowers on long stiff stems, a perfect keeper when cut, as a color it is the nearest thing to a purple that I know of, and was a big attraction at the $\mathrm{N}$. Y. Show where it looked just as good the last day of the show as it did when cut four davs before. This Dahlia was originated by Mr. Herman Rindfleisch of Mamaroneck, N. Y., a perfect type Decorative making fine clumps or roots from either plants or tubers.

Plants $\$ 2.00$; Tubers $\$ 3.00$

PEARL DE LYON. H. C. White, with cleft petals.

Tubers only, $35 c$

PIERROTT. Cac. Deep amber, boldly tipped white. An exceptionally large and striking variety.

Tuber only, $75 \mathrm{c}$

PRESIDENT WILSON. Dec. Large deep relvety red, the points of the petals tipped white making this a most attractive variety, very free flowering and splendid for garden decoration, the best fancy decorative grown.

Plants $\$ 1.00$; Tubers $\$ 1.50$ 
PATRICK O'MARA. Dec. A fine, large, stiff stem variety of an unusually soft and pleasing shade of orange buff slightly tinged Neyron rose. A rare Autumn shade which will be in demand particularly as a cut flower variety.

Plants only, 75c

PETITE MARIE. Dec. A fine rose pink lovely shaped flower, petals losely formed making it look so much like a water lily that one misses the odor that the water lily has.

Plants only, 75c

PAUL MICHAEL. Dec. Incorrectly named California Gold. An immense flower of bright apricot and bronze shadings. Good stems and unexcelled for exhibition. It belongs in the Largest Dahlia class, having won that prize three times in this vicinity in the last two years.

Plants only, $75 \mathrm{c}$

PARAMOUNT. D. A perfectly formed compact flower of good size, rose pink, penciled and stained darker. Every garden not complete without this one.

Plants $\$ 1.00 ;$ Tubers $\$ 2.00$

ROOKWOOD. Dec. This dahlia is of an entirely new shade of rose, similar to the Mrs. Chas. Russell rose, pure bright cerise rose, without the faintest touch of magenta, and is as beautiful under artificial light as the Russel rose. Flowers are large, with a good depth, and are heid aloft on splendid stems. The bushes grow low and spreading and are always a mass of blooms.

Plants only, $\$ 1.00$

ROSE NELL. Dec. Clear bright rose color, flowers very large, fine for exhibition, good keeper, one of the best shaped decorative dahlias in existence, is a rare color and attracts immediate attention wherever seen.

Plants $75 c$; Tubers $\$ 2.00$

RADIO. A blending of red and gold, a very large flower good for exhibition, stems hold the flower but are short. Plants $\$ 2.00$; Tubers $\$ 4.00$

ROSA BONHEUR. Dec. A graceful combination of dainty form and clear color. Ivory white center, shading to a beautiful shellpink. Free blooming and splendid stem. The outer petals prettily twisted and curled, gives a graceful appearance. Good in color, form, texture and stem. Prize winner. Plants only, $\$ 2.00$

ROBERT TREAT. Dec. This dahlia, similar in color to the American Beauty rose, is different from any other dahlia in shade or color. Plants are strong, healthy growers of spreading habit. Flowers from 7 to 8 inches and 4 inches deep, produced on long, erect stems. Has a wonderful prize record and certainly an outstanding novelty.

Plants $\$ 2.00$; Tubers $\$ 4.00$

SUSAN COE. P. * A splendid flower of perfect form and size, carried on long stiff wiry stems, the outer petals a pleasing shade of rose pink passing to a yellow center suffused salmon, as the season advances this variety develops from a perfect decorative into a lovely peony dahlia, a very large flower.

Plants $\$ 1.00$; Tubers $\$ 2.00$ 
SNOWDRIFT. Dec. One of the best white decoratives we have ever seen. A rery deep built immense flower, with broad, waxy, pure white petals. The blooms open quickly remaining perfect for a week. Fine for exhibition.

Plants 75c; Tubers $\$ 1.00$

SUSAN G. TEVIS. Dec. One of the largest and most perfectly formed decoratives in existence. N oother dahia closely resembles it. The color of this stately flower is a deep shade of lilac with a bluish sheen. The plant is unusually rigorous and the foliage dark and rich. The large blooms are supported on exceptionally strong stems.

Plants only, $\$ 2.00$

SUNNY SOUTH. H. C. A monster bright yellow on very strong stems, a wonderfully attractive flower.

Plants only, $\$ 2.50$

SUNNY JERSEY (I)ahliadel 1925). Dec. This is a free bloomer with flowers a foot or more above the foliage on erect stems. A fine cut flower and the best yellow that I know of. Plants only, $\$ 1.50$ old Sulphurea. Fine long stem and the best cut flower (white) that I know of. Tried it out at the New Haven Horticultural Flower Show where it surprised me with its keeping and exhibition qualities. Plants $\$ 2.00$; Tubers $\$ 5.00$

STAR WHITE. H. C. This dahlia was originated by Mr. H. E. Loveland of Hudson Falls, N. Y. and has proved to be all that he said it was. A rery fine snow white flower a good deal of the type of the old Sulphurea but a larger flower. Fine long stem and the best cut flower (white) that I know of. Tried it out at the New Haven Horticultural Flower Show where it surprised me with its keeping and exhibition qualities.

Plants $\$ 2.00$; Tubers $\$ 5.00$

THE EMPEROR. Dec. A maroon dahlia of the finest type, made up of long flat petals, color does not spot under any weather conditions and flower is of enormous size borne on long stiff stems. An exhibition variety of exceptional merit.

Plants $\$ 1.00$; Tubers $\$ 2.00$

UNCLE SAM. A monster dahlia in size. Color orange buff, shading bitter sweet pink at tips. Stems extra long.

Plants only, $\$ 1.50$

VIOLA D. BRYANT. H. C. A delightful shade of rose pink, ver free flowering, medium size and long wiry stems, an ideal cut flower.

Plants 75c; Tubers $\$ 1.50$

VENUS. Dec. This very lovely variety, large flowers being produced freely on strong stiff stems. While it is most attractive in the garden, its special value is for cut flowers. Considered by many exhibitors and dahlia experts as one of the most meritorious varieties. The color is a soft beautiful shade of creamy white with lavender suffusion. Extra fine grower. Average height 4 feet.

Plants 75c, Tubers $\$ 1.00$ 
WORLDS BEST WHITE. H. Dec. Mr. Murphy claims this is best white, and it certainly is a wonder for bloom, size, stem, quality, everything to be desired; but it shows a decided creamy center. As a bloomer it's the best white I know. Plants $\$ 1.00$; Tubers $\$ 1.50$

WILLIAM SLOCOMBE. Dec. A fine large flower carried on stiff stems, well formed, canary yellow shading to a pale lemon towards the centre, fine for cutting.

Plants 75c; Tubers $\$ 1.50$

In reference to green plants, as there has been so much objection to green plants, I will say that I guarantee my plants to be strong and healthy and get to the customer in perfect condition.

I find green plants better than tubers as they are less liable to become diseased than rots, and produce as good flowers, as well as better tubers, which are cleaner and more free from disease. Moisten the soil before removing from the pot, so as not to disturb the roots, cover with soil to first set of leaves and as the plants grow fill in the soil till level with the surface. It is best to set out plants late in afternoon or on a cloudy day, and they should be watered well if no rain follows.

Give them the same care as for tubers. They should be planted about two to three inches deeper than tubers, in order to make new tubers, and again, fi cut worms should destroy the top of plant, it will almost always send up new shoots from the joints below the ground. 


\section{CULTIVATION OF DAHLIAS}

Dahlias are easily grown, requiring no special soil or treatment to bring them to perfection. They love an open sumny location but succeed in partial shade. Prepare soil thoroughly by digging 12 to 18 inches deep, possibly in the fall and then again in the spring, before planting.

If the soil is poor, work in some well-rotted stable manure, or artificial fertilizer, but don't overdo this.

Dig holes 3 feet apart and about 6 inches deep; drive a stout stake in each hole, and lay the tuber down flat, with the eyes to the stake, and cover with two or three inches of fine soil, leaving the hole to be filled after the plant comes up.

Plant any time between April 1st and June 15th.

When the plants have made their third set of leaves, cut out the top, to make them branch.

The most important thing from now on is hoeing and cultivating the soil, until the buds appear; then give the beds a good mulching of manure, to keep the ground moist; and water the plants thoroughly once or twice a week.

Disbudding side buds leaving only terminal bud to develop will bring larger blossoms.

Tubers should be stored in a dry cellar or basement, cover them with dry sand or soil to keep from shriveling. Divide the tubers in the spring after the eyes show plainly, being carefuly that each tuber has an eye, corer them again and keep dry until planted.

Join the American Dahlia Society and receive the quarterly "Bulletin" of the Society, giving all the latest information regarding dahlias, and report of the Trial Grounds. Address for sample copy.

Wm. J. Rathgeber, 198 Norton Street, New Haven, Conn. 

